\title{
MONITORING AND PREVENTION OF LAMENESS IN A DAIRY CATTLE HERD
}

\section{MONITOROWANIE I ZAPOBIEGANIE KULAWIŹNIE W STADZIE BYDŁA MLECZNEGO}

Department of Breeding and Genetic Resources Conservation of Cattle, University of Life Sciences in Lublin, Poland

\begin{abstract}
Streszczenie. Choroby racic u krów mlecznych utrzymywanych w intensywnych systemach produkcji występują równie często jak zapalenie wymion (mastitis), choroby układu rozrodczego i zaburzenia metaboliczne. Istotne jest stałe kontrolowanie zachowań i aktywności ruchowej krów oraz opracowanie obiektywnych metod oceny ich lokomocji i wczesnego wykrywania kulawizn. Kulawizny charakteryzują się wieloczynnikową etiologią obejmującą aspekty genetyczne i technologiczne, warunki utrzymania, a także, w znacznym stopniu, żywienie, pielęgnację i higienę zwierząt. Znajomość przyczyn powstawania chorób racic i metod profilaktyki oraz umiejętność szybkiej diagnostyki i leczenia kulawizn mogą przyczynić się do skrócenia procesu chorobowego i poprawy wyników produkcyjnych stada.
\end{abstract}

Key words: locomotion, motor activity of cows, hoof diseases, lameness, losses in production. Słowa kluczowe: lokomocja, aktywność ruchowa krów, choroby racic, kulawizna, straty produkcyjne.

\section{INTRODUCTION}

The last 20 years have seen intensive growth of modern technologies associated with dairy cattle farming. These changes can be seen on farms where facilities have become modernized and tie-stall housing has been replaced by free-stall systems, as well as where an automatic milking system (AMS) has been introduced. This is linked to an increase in the animals' motor activity, which is not always spontaneous. In modern housing systems dairy cows move freely and regulate the intensity and frequency of movement. For this reason their behaviour and motor activity must be continually monitored and objective methods must be developed for evaluation of their locomotion and early detection of lameness.

\section{LOCOMOTION IN COWS}

During correct locomotion cows maintain a level back and their pelvic limbs are nearly in line with the thoracic limbs. In observing a moving cow we can distinguish three stages of locomotion: the weight-bearing phase, the forward phase (protraction) and the backward

Corresponding author - Adres do korespondencji: Waldemar Teter, Department of Breeding and Genetic Resources Conservation of Cattle, University of Life Sciences in Lublin, Akademicka 13, 20-950 Lublin, Poland, e-mail: waldemar.teter@up.lublin.pl 
phase (retraction). During the weight-bearing stage, in the thoracic limb the tip of the hoof touches the ground first, followed by the rest of the sole. The entire limb is straightened. In the case of the pelvic limb, the heel touches the ground first, followed by the edge of the claw wall and its tip. The limb is not straightened out, but remains at an angle of 145-155 degrees from the ground. The second stage involves throwing the limb forward until it touches the ground. The final stage of movement is retraction, when the weight of the body is transferred forward and locomotion takes place, while the pelvic limb is thrown backwards (Greenough 2007; Gîscă 2012).

\section{SUBJECTIVE EVALUATION OF LOCOMOTION}

To evaluate locomotion in cows we can use a subjective 5-point scale according to Sprecher et al. (1997). According to this scale animals receiving a score of 1 are considered healthy. Such cows exhibit correct back posture at rest and in motion, and their limbs are correctly placed. Cows that limp slightly and arch their back a bit while walking receive a score of 2 . When the animals are standing their back posture is correct. Cows with a locomotion score of 3 show moderate limping with an arched back both while walking and while standing. A shortened stride is observed as well. A score of 4 refers to cows with a permanently arched back and an impaired forward step in at least one limb. Animals with a score of 5 have a severe limp and a permanent pronounced arch of the back, and are extremely unwilling or even unable to transfer their weight onto the affected limbs. Moreover, they have difficulty rising from a recumbent position.

\section{OBJECTIVE EVALUATION OF LOCOMOTION}

Objective systems for evaluating locomotion in cows are usually based on automated computer systems with quantitative numerical values corresponding to a type of gait (Tasch and Rajkondawar 2004; Flower and Weary 2006; Rajkondawar et al. 2006; Pastell et al. 2008; Song et al. 2008; Martiskainen et al. 2009; Pastell et al. 2009).

Objective methods are more reliable and sensitive, but their practical and clinical use is limited by the high cost of using specialized devices in diagnostics and practice (Clayton and Schamhardt 2001; Wójcik and Rudziński 2014).

\section{LAMENESS}

Lameness is a crucial problem affecting production and welfare in modern dairy cattle farming. The welfare of cows is linked to ethical quality of production, and lameness is one of its main problems (Cook 2003; Whay et al. 2003; Cook et al. 2004; Cook et al. 2005; Hristov et al. 2008; Laven et. al. 2008; Cook and Nordlund 2009; Dippel et al. 2009). The comfort of cows while recumbent and in motion is of great importance as a factor limiting the occurrence of lameness. Lameness itself should not be treated as a disease, because a disease is a change in the structure or functioning of the organism, while lameness is merely the consequence of these abnormalities (Porter et al. 2010). 


\section{CAUSES OF LAMENESS}

Four categories of causes of lameness in cattle can be distinguished. The first involves claw horn disruption, which causes haemorrhaging within the sole or white line, and in consequence the formation of ulcers and abscesses at these sites. The second category consists of inflammation due to infections of the skin of the toes and the claw horn. The third is classic laminitis, and the fourth group induces skin necrosis (Webster et al. 2005).

Lesions in the hoof and legs cause pain and discomfort when the animal stands or walks, which is manifested as lameness (Warnick et al. 2001). This leads to reduced milk production and increased culling of cows, which in turn generates significant economic losses. Hoof diseases in dairy cattle occur with the same frequency and can be just as costly as mastitis, diseases of the reproductive system or metabolic disorders (Nałęcz-Tarwacka and Jędrzejek 2012).

Over the last 20 years the incidence of lameness has continually increased, and it is currently observed at least once a year in over half of dairy cows (Vermunt and Greenough 1994; Hernandez et al. 2000; Tadich et al. 2010).

Lameness has a multifactorial aetiology including aspects of genetics, diet, and above all technology, associated with the housing and care of the animals, the equipment used on the farm and, to a significant extent, the animals' diet.

Table 1. Incidence of hoof diseases in cows according to various authors

Tabela 1. Częstość występowania chorób racic u krów według różnych autorów

\begin{tabular}{lcccc}
\hline & \multicolumn{4}{c}{$\begin{array}{c}\text { Incidence of disease } \\
\text { Częstotliwość chorób [\%] }\end{array}$} \\
\cline { 2 - 5 } & $\begin{array}{c}\text { Green } \\
\text { et al. (2014) }\end{array}$ & $\begin{array}{c}\text { Navarro } \\
\text { et al. (2013) }\end{array}$ & $\begin{array}{c}\text { De Frain } \\
\text { et al. (2013) }\end{array}$ & $\begin{array}{c}\text { Winkler and } \\
\text { Margerison } \\
\text { (2012) }\end{array}$ \\
\hline $\begin{array}{l}\text { Sole ulcer } \\
\text { Wrzód podeszwy }\end{array}$ & 38.68 & 6.84 & 21.05 & 17.14 \\
$\begin{array}{l}\text { Bruised sole } \\
\text { Krwawe podbicia }\end{array}$ & 12.98 & 10.00 & 1.43 & 28.57 \\
$\begin{array}{l}\text { Digital dermatitis } \\
\text { Zapalenie skóry palca }\end{array}$ & 10.00 & & 47.67 & 22.86 \\
$\begin{array}{l}\text { White-line disease } \\
\text { Choroba linii białej }\end{array}$ & 8.28 & 16.32 & 17.26 & 5.71 \\
$\begin{array}{l}\text { Interdigital growth } \\
\text { Międzyraciczak } \\
\text { Overgrown claw } \\
\text { Skręcenie racicy/wyrośnięcie }\end{array}$ & 4.50 & 6.84 & 0.19 & 2.86 \\
$\begin{array}{l}\text { Toe ulcer } \\
\text { Wrzód czubka palca }\end{array}$ & 3.11 & 3.68 & 1.08 & - \\
$\begin{array}{l}\text { Double sole } \\
\text { Podwójna podeszwa } \\
\text { Hoof wall cracks } \\
\text { Szczeliny w rogu } \\
\text { Heel erosion } \\
\text { Nadżerki opuszki }\end{array}$ & 1.79 & 3.68 & 2.61 & - \\
$\begin{array}{l}\text { Other } \\
\text { Inne }\end{array}$ & 7.42 & 6.84 & - & - \\
\hline & - & 8.42 & 0.33 & - \\
\hline
\end{tabular}


Research in the United Kingdom has shown that the leading cause of lameness - in about $25 \%$ of cases - is bacterial infections, including anaerobic bacteria. Cases have most often involved ulcers (27\%), white-line diseases (20\%) and skin conditions (16\%) (Amory et al. 2006).

Most lesions in hooves do not cause pronounced symptomatic lameness and thus can be difficult to detect when only the cow's gait and posture are evaluated (Manske 2002; Manske et al. 2002). In $70 \%$ of examined cows hoof disease was not detected until the hooves were trimmed (Green et al. 2002).

\section{EXAMPLES OF NON-INFECTIOUS DISEASES}

Sole ulcer (sole ulceration, Rusterholz ulcer, pododermatitis septica circumscripta) causes varying degrees of lameness, which may be weakly manifested if ulceration is present in both of the front or rear limbs. The most characteristic symptom, appearing before lameness, is bruising in the area typical for this disorder. However, this is not visible until about 6-10 weeks after its appearance, because only then does the bruising appear on the sole surface (Empel 1984; Greenough 2007).

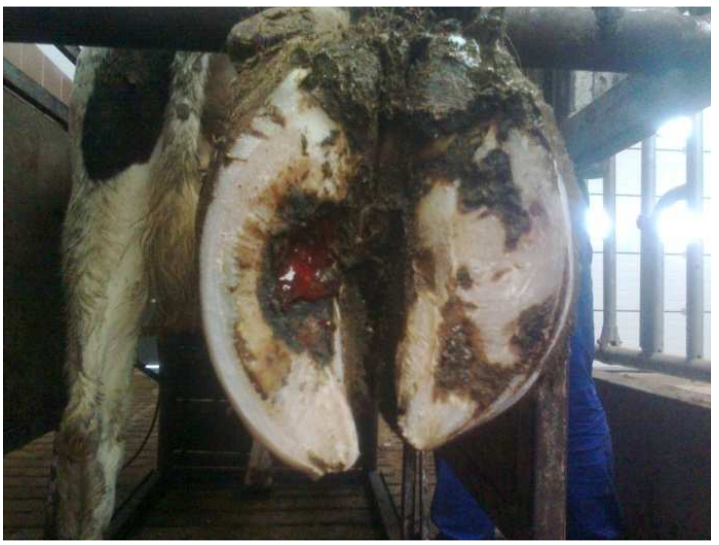

Fig. 1. Sole ulcer

Ryc. 1. Wrzód podeszwy (E. Flis)

Heel erosion (slurry heel) - in the initial stage of the disease we can observe pits in the claw horn, which over time merge to form irregular, jagged edges. The most frequently observed symptoms are a deep V-shaped groove and dark discoloured horn in the affected site (Empel 1984; Greenough 2007).

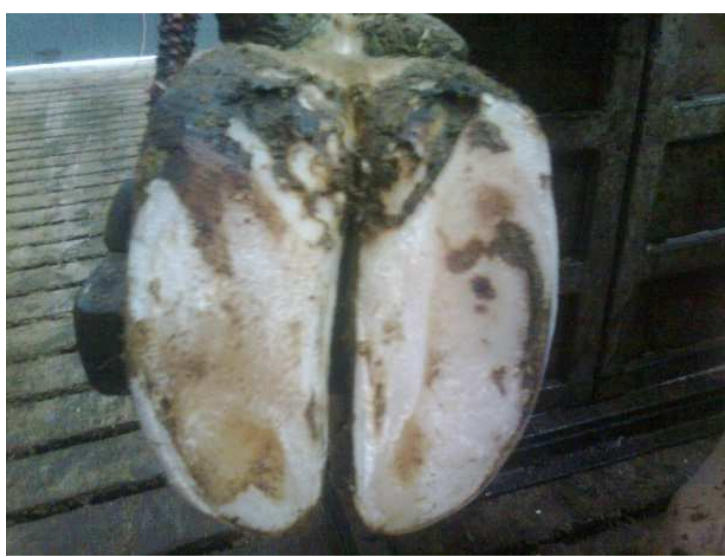

Fig. 2. Heel erosion

Ryc. 2. Nadżerki opuszki (E. Flis) 
White line disease (claw-wall separation) - an animal with this disease may walk with the limb abducted to the side, and while standing it may place its entire weight on the median claw (Empel 1984; Greenough 2007).

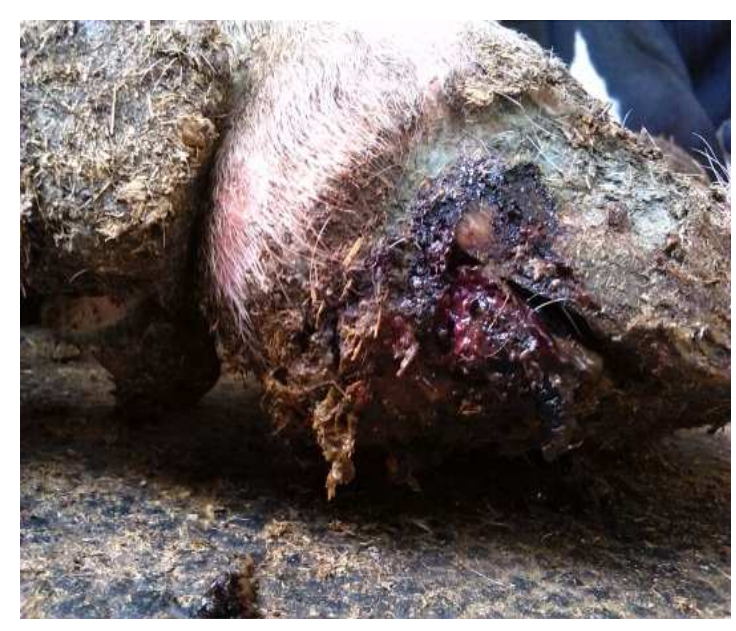

Fig. 3. White-line disease

Ryc. 3. Choroba linii białej (E. Flis)

Double sole - this disease usually affects all the hooves. Lameness is rarely observed, and the disease is detected during routine hoof trimming (Empel 1984; Greenough 2007).

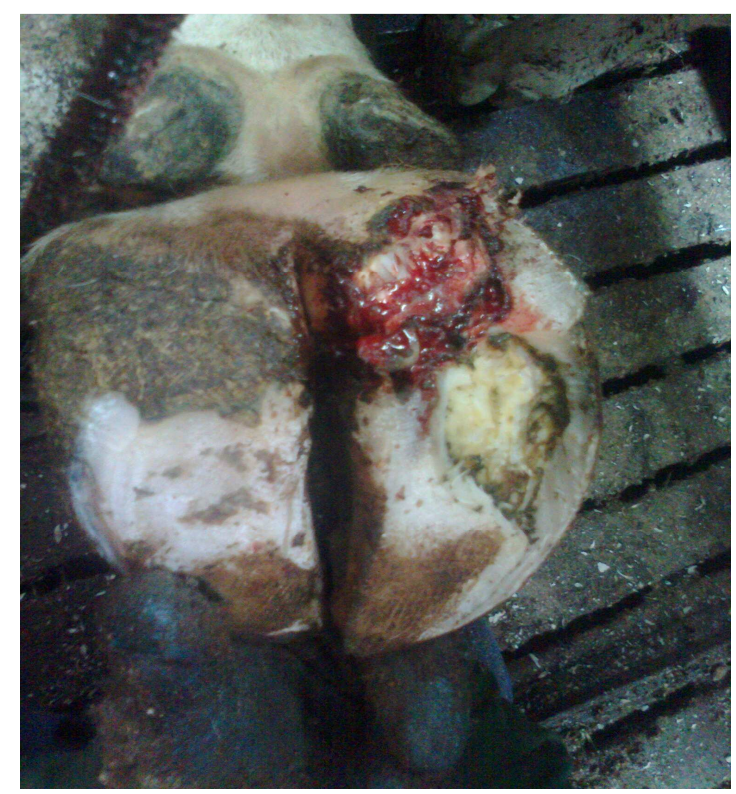

Fig. 4. Double sole

Ryc. 4. Podwójna podeszwa (E. Flis)

\section{INFECTIOUS DISEASES}

Interdigital phlegmon (interdigital necrobacillosis, foot rot, foul-of-the-foot) - typical symptoms are sudden onset of lameness, interdigital swelling resulting in separation of the toes, secondary interdigital necrosis, and the presence of pus and a characteristic foul odour (Empel 1984; Greenough 2007). 


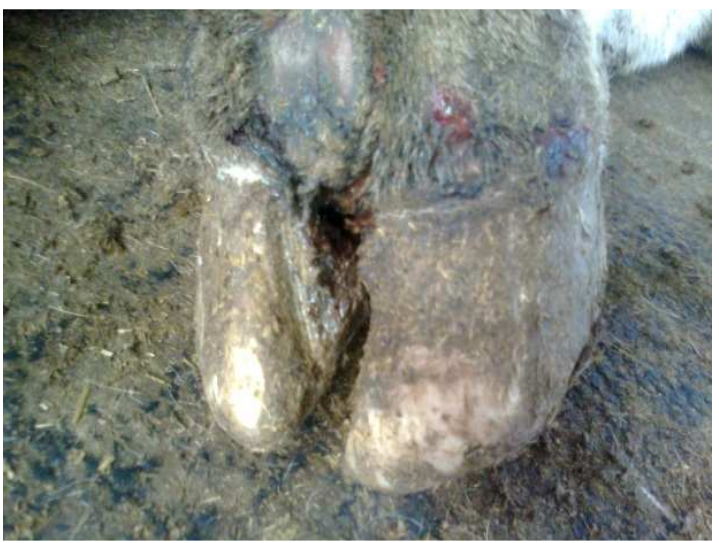

Fig. 5. Interdigital phlegmon

Ryc. 5. Ropowica międzypalcowa (E. Flis)

Digital dermatitis (papillomatous digital dermatitis, Mortellaro's disease, heel warts, hairy footwarts, strawberries, strawberry heel) - a superficial ulceration of the hairless skin between the claws and the rear segment of the interdigital space. Lesions are small (about $0.5-1 \mathrm{~cm}$ ), round or oval, red or brown, with a tendency to bleed, and often surrounded by a white margin (Empel 1984; Greenough 2007).

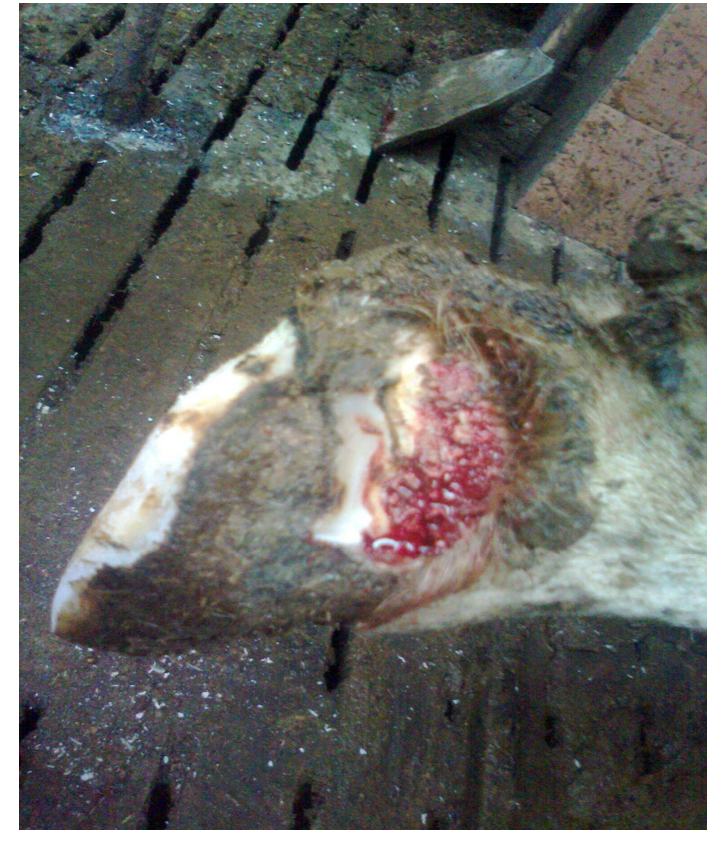

Fig. 6. Digital dermatitis (E. Flis)

Ryc. 6. Zapalenie skóry palca (E. Flis)

\section{PREVENTION OF LAMENESS}

Prevention of hoof disease should include improving the comfort of cows (maximized lying time, comfortable bedding surface, suitable surfaces for walking and standing), proper hygiene (a dry environment), social and physical integration of heifers and dry cows, ease of movement of cows on the farm (undamaged floor surfaces in barns and passage corridors), proper diet (macro- and micronutrients), and routine professional functional and preventive hoof trimming (Hristov et al. 2008). 
Hoof trimming reduces the incidence of lameness, provided it is done correctly. One of the main functions of hoof trimming is to detect lesions in the early, subclinical stage before the appearance of clinical symptoms or serious damage. The second, extremely important function is to prevent hoof damage through early correction of pressure. This is one of the main factors reducing the risk of disease, regardless of the technique applied. Hoof trimming performed before calving reduces the incidence of lameness in comparison with cows in which the procedure is not performed (Grove-White 2004).

Hoof trimming twice a year reduces the incidence of sole ulcers by half. After properly performed hoof trimming the animal's weight is optimally distributed on all limbs, as well as within the hooves (Bergsten et al. 1998). According to Somers et al. (2005), cows whose time in the pasture or pen is limited, so that they are exposed to high moisture levels, have an increased risk of dermatitis. Both improving cleanliness and decreasing stocking density can be factors determining hoof health.

The quantitative and qualitative composition of feed rations plays a significant role in limb health in dairy cows. The use of feed rations based on fodder with high starch content causes rapid fermentation, leading to ruminal acidosis. This in turn affects the quality of the claw horn, which becomes softer and thus more likely to become worn down or cracked, increasing the risk of damage (Amory et al. 2006). High intake of non-fibre carbohydrates (NFC) accompanied by low intake of non-digestible fibre (NDF) lowers the $\mathrm{pH}$ of the rumen and causes secretion of histamine and endotoxins, which enter the bloodstream and damage the capillaries in the hooves, thereby producing horn tissue of lower quality (Bramley et al. 2008, Bicalho et al. 2009; Lean et al. 2013). A high level of protein increases the rate of growth of the hoof horn, which may lead to overgrowth and incorrect distribution of pressure, thereby causing a risk of hoof damage and prolonging lameness (Manson and Leaver 1988).

The supply of micro- and macronutrients and vitamins in the feed ration plays an important role in the quality of horn tissue. Deficiencies of sulphur, copper, zinc, selenium, manganese, cobalt, retinol or biotin, i.e. elements and vitamins taking part in keratin metabolism, reduce horn quality, having a detrimental effect on hoof health. Moreover, copper, zinc, selenium and manganese are components of antioxidant enzymes. Oxidative stress damages the capillaries in the hoof and thus interferes with the supply of oxygen and nutrients, leading to poorer horn quality (Tomlinson et. al. 2004; Seyrek et.al. 2008; Lean and Rabiee 2011; Al-Qudah and Ismail 2012).

Another important factor determining hoof health is flooring. The use of floors that ensure friction, and therefore better traction, is recommended to improve locomotion. Given a choice of hard or soft flooring, cows generally choose the soft option for both standing and walking. It is also recommended that the floor should be kept clean and that cows should not stay or move on wet or slippery floors soiled with excrement (Rushen and de Passille 2006; Flower et al. 2007; Telezhenko et al. 2008).

\section{CONCLUSIONS}

Lameness has a multi-factored aetiology including genetic and technological aspects, housing conditions, and to a large extent the animals' diet, care and hygiene. The occurrence and economic significance of lameness continues to be underestimated by farmers, 
consultants and veterinarians. In this regard it is necessary to examine the herd, identify the scale of the problem and implement a comprehensive corrective programme including all known factors exacerbating the problem of lameness in the herd.

A necessary condition for combating lameness is improvement of animal welfare, including all of the following:

1) housing conditions

- cow barns with adequate space for the cows to lie down and stand up and soft flooring encouraging them to lie down;

- frequent cleaning and bedding of stalls, grates, floors and passages;

- good ventilation, to keep floors and hooves dry;

- unconstrained movement by the cows, to minimize standing and waiting time;

- additional bedding in stalls for cows immediately after calving and for lame cows, to ensure additional comfort;

- optimal stocking density;

2) care and hygiene

- regular prophylactic hoof baths;

- hoof trimming twice a year (prophylactic and ad hoc);

- medical treatment;

3) diet

- prevention of acidosis;

- elimination or reduction of excess protein in feed rations;

- increased supply of macro- and micronutrients (enriched salt licks).

\section{REFERENCES}

Al-Qudah K.M., Ismail Z.B. 2012. The relationship between serum biotin and oxidant/antioxidant activities in bovine lameness. Res. Vet. Sci. 92, 138-141.

Amory J.R., Barker Z.E., Wright J.L., Mason S.A., Blowey R.W., Green L.E. 2006. LAMECOW at the University of Warwick: A study of lameness in dairy cattle. Cattle Prac. 14, 132-125.

Bergsten C., Hultgren J., Manske T. 1998. Claw traits and foot lesions in Swedish dairy cows in relation to trimming interval and housing. A preliminary report, in: 10th International Symposium on Disorders of the Ruminant Digit, Lucerne, September 7-10, 1998. Eds. P. Ossent, C. Lischer. Lucerne, University of Zürich, 46-48.

Bicalho R.C., Machado V.S., Caixeta L.S. 2009. Lameness in dairy cattle: A debilitating disease or a disease of debilitated cattle? A cross-sectional study of lameness prevalence and thickness of the digital cushion. J. Dairy Sci. 92, 3175-3184.

Bramley E., Lean I.J., Fulkerson W.J., Stevenson M.A., Rabiee A.R., Costa N.D. 2008. The definition of acidosis in dairy herds predominantly fed on pasture and concentrates. J. Dairy Sci. 91, 308-321.

Clayton H.M., Schamhardt H.C. 2001. Measurement techniques for gait analysis, in: Equine locomotion. Eds. W. Back, H.M. Clayton. London, UK, W.B. Saunders, 55-76.

Cook N.B. 2003. Prevalence of lameness among dairy cattle in Wisconsin as a function of housing type and stall surface. J. Amer. Vet. Med. Assoc. 223, 1324-1328.

Cook N.B., Bennett T.B., Nordlund K.V. 2004. Effect of free stall surface on daily activity patterns in dairy cows with relevance to lameness prevalence. J. Dairy Sci. 87, 2912-2922.

Cook N.B., Bennett T.B., Nordlund K.V. 2005. Monitoring indices of cow comfort in free-stall-housed dairy herds. J. Dairy Sci. 88, 3876-3885. 
Cook N.B., Nordlund K.V. 2009. The influence of the environment on dairy cow behavior, claw health and herd lameness dynamics. Vet. J. 179, 360-369.

De Frain J.M., Socha M.T., Tomlinson D.J. 2013. Analysis of foot health records from 17 confinements dairies. J. Dairy Sci. 96, 7329-7339.

Dippel S., Dolezal M., Brenninkmeyer C., Brinkmann J., March S., Knierim U., Winckler C. 2009. Risk factors for lameness in cubicle housed Austrian Simmental dairy cows. Prev. Vet. Med. 90, 102-112.

Empel W. 1984. Higiena i choroby narządów ruchu bydła. PWRiL, Warszawa. [in Polish]

Flower F.C., Weary D.M. 2006. Effect of hoof pathologies on subjective assessments of dairy cow gait. J. Dairy Sci. 89, 139-146.

Flower F.C., de Passillé A.M., Weary D.M., Sanderson D.J., Rushen J. 2007. Softer, higher-friction flooring improves gait of cows with and without sole ulcers. J. Dairy Sci. 90, 1235-1242.

Gîscă E.D. 2012. The characteristics of lameness in dairy cows. Sci. Works, Ser. C Veterinary Medicine 58(4), 190-197.

Green L.E., Hedges V.J., Schukken Y.H., Blowey R.W., Packington A.J. 2002. The impact of clinical lameness on the milk yield of dairy cows. J. Dairy Sci. 85, 2250-2256.

Green L.E., Huxley J.N., Banks C., Green M.J. 2014. Temporal associations between low body condition, lameness and milk yield in a UK dairy herd. Prev. Vet. Med. 113, 63-71.

Greenough P.R. 2007. Bovine laminitis and lameness. A hands-on approach. St. Louis, Missouri, Saunders Elsevier, 312.

Grove-White D. 2004. Healthcare in the modern dairy herd. In Pract. 26(7), 368-376.

Hernandez J., Shearer J.K., Webb D.W. 2000. Effect of papillomatous digital dermatitis and other lameness disorders on reproductive performance in a Florida herd, in: Proceedings 11th International Symposium on Disorders of the Ruminant Digit \& III International Conference on Bovine Lameness, Parma, September 3-7, 2000. University of Parma, Italy, 353-357.

Hristov S., Stanković B., Zlatanović Z., Joksimović Todorović M., Davidović V. 2008. Rearing conditions, health and welfare of dairy cows. Biotech. Anim. Husb. 24(1-2), 25-35.

Laven R.A., Lawrence K.E., Weston J.F., Dowson K.R., Stafford K.J. 2008. Assessment of the duration of the pain response associated with lameness in dairy cows, and the influence of treatment. New Zeal. Vet. J. 56, 210-217.

Lean I.J., Rabiee A.R. 2011. Effect of feeding biotin on milk production and hoof health in lactating dairy cows: a quantitative assessment. J. Dairy Sci. 94, 1465-1476.

Lean I.J., Westwood C.T., Golder H.M., Vermunt J.J. 2013. Impact of nutrition on lameness and claw health in cattle. Livest. Sci. 156, 71-87.

Manske T. 2002. Hoof lesions and lameness in Swedish dairy cattle: Prevalence, risk, factors, effects of claw trimming and consequences for productivity. PhD thesis. Skara, SLU, Swedish University of Agricultural Sciences.

Manske T., Hultgren J., Bergsten C. 2002. The effect of claw trimming on the hoof health of Swedish dairy cattle. Prev. Vet. Med. 54, 113-129.

Manson F.J., Leaver J.D. 1988. The influence of dietary protein intake and of hoof trimming on lameness in dairy cattle. Anim. Sci. 47, 191-199.

Martiskainen P., Järvinen M., Skön J., Tiirikainen J., Kolehmainen M., Mononen J. 2009. Cow behaviour pattern recognition using a three-dimensional accelerometer and support vector machines. App. Anim. Behav. Sci. 119, 32-38.

Nałęcz-Tarwacka T., Jędrzejek D. 2012. Influence of the selected hoof diseases on reproduction parameters of Polish HF cows. Acta Sci. Pol., Ser. Zootech. 11(4), 79-90.

Navarro G., Green L.E., Tadich N. 2013. Effect of lameness and lesion specific causes of lameness on time budgets of dairy cows at pasture and when housed. Vet. J. 197, 788-793.

Pastell M., Kujala M., Aisla A.M., Hautala M., Poikalainen V., Praks J., Veermäe I., Ahokas J. 2008. Detecting cows lameness using force sensors. Comput. Electron. Agric. 64(1), 34-38. 
Pastell M., Tiusanen J., Hakojärvi M., Hänninen L. 2009. A wireless accelerometer system with wavelet analysis for assessing lameness in cattle. Biosys. Eng. 104, 545-551.

Porter R.S., Kaplan J.L., Homeier B.P. 2010. Objawy kliniczne. Praktyczny przewodnik diagnostyki i terapii. Wrocław, Wydaw. Elsevier Urban \& Partner. [in Polish]

Rajkondawar P.G., Liu M., Dyer R.M., Neerchal N.K., Tasch U., Lefcourt A.M., Erez B., Varner M.A. 2006. Comparison of models to identify lame cows based on gait and lesion scores, and limb movement variables. J. Dairy Sci. 89, 4267-4275.

Rushen J., Passillé A.M. de. 2006. Effects of roughness and compressibility of flooring on cow locomotion. J. Dairy Sci. 89, 2965-2972.

Seyrek K., Yaylak E., Akşıt H. 2008. Serum sialic acid, malondialdehyde, retinol, zinc, and cooper concentrations in dairy cows with lameness. Bull. Vet. Inst. Pulawy 52, 281-284.

Somers J.G., Frankena K., Noordhuizen-Stassen E.N., Metz J.H. 2005. Risk factors for digital dermatitis in dairy cows kept in cubicle houses in the Netherlands. Prev. Vet. Med. 71, 11-21.

Song X., Leroy T., Vranken E., Maertens W., Sonck B., Berckmans D. 2008. Automatic detection of lameness in dairy cattle. Vision-based trackway analysis in cow's locomotion. Comput. Electron. Agric. 64(1), 39-44.

Sprecher D.J., Hostetler D.E., Kaneene J.B. 1997. A lameness scoring system that uses posture and gait to predict dairy cattle reproductive performance. Theriogenology 47, 1179-1187.

Tadich N., Flor E., Green L. 2010. Associations between hoof lesions and locomotion score in 1098 unsound dairy cows. Vet. J. 184(1), 60-65.

Tasch U., Rajkondawar P.G. 2004. The development of SoftSeparatorTM for a lameness diagnostic system. Comput. Electron. Agric. 44, 239-245.

Telezhenko E., Bergsten C., Magnusson M., Ventorp M., Nilsson C. 2008. Effect of different flooring systems on weight and pressure distribution on claws of dairy cows. J. Dairy Sci. 91, 1874-1884.

Tomlinson D.J., Mülling C.H., Fakler T.M. 2004. Invited review: formation of keratins in the bovine claw: roles of hormones, minerals, and vitamins in functional claw integrity. J. Dairy Sci. 87, 797809.

Vermunt J.J., Greenough P.R. 1994. Predisposing factors of laminitis in cattle. Br. Vet. J. 150, 151-164.

Warnick L.D., Janssen D., Guard C.L., Grohn Y.T. 2001. The effect of lameness on milk production in dairy cows. J. Dairy Sci. 84, 1988-1997.

Webster A.J.T., Knott L., Tarlton J.F. 2005. Understanding lameness in the dairy cow. Cattle Pract. 13, 93-98.

Whay H.R., Main D.C., Green L.E., Webster A.J. 2003. Assessment of the welfare of dairy cattle using animal-based measurements: Direct observations and investigation of farm records. Vet. Rec. 153, 197-202.

Winkler B., Margerison J.K. 2012. Mechanical properties of the bovine claw horn during lactation. J. Dairy Sci. 95, 1714-1728.

Wójcik P., Rudziński J. 2014. Effectiveness of using activity tags in management of high-producing dairy herd. Folia Pomer. Univ. Technol. Stetin., Agric., Aliment., Pisc., Zootech. 315(32), 59-66.

Abstract. Hoof diseases in dairy cows maintained in the intensive production system occur with the same frequency as udder inflammation (mastitis), diseases of the reproductive system and metabolic disorders. Behaviour and motor activity of cows must be continually monitored and objective methods must be developed for evaluation of their locomotion and early detection of lameness. Lameness has a multi-factored aetiology including genetic and technological aspects, housing conditions, and to a large extent the animals' diet, care and hygiene. Knowledge of causes of hoof diseases and prevention methods, as well as the ability to diagnosis and rapid treatment of lameness contribute to shorten the period of illness and improve production results. 